\title{
KONCEPCJA USPRAWNIENIA PROCESÓW PRZYGOTOWANIA I URUCHOMIENIA PRODUKCJI
}

\begin{abstract}
W opracowaniu przedstawiono koncepcję zintegrowanego środowiska informatycznego realizującego funkcje z zakresu przygotowania dokumentacji technicznej produktu, wygenerowania harmonogramu produkcyjnego oraz monitorowania produkcji w toku. Proces i model danych zakłada wprowadzenie zmian w stosunku do tradycyjnego podejścia w zakresie tworzenia i opisu proces technologicznego wytwarzania produktu polegających na zastosowaniu uproszczonych procesów technologicznych dołączanych przez system automatycznie do struktury produktu. Zastosowanie takiej koncepcji pracy w działach rozwoju produktu pozwoli na skrócenie czasu opracowania dokumentacji technologicznej produktu i jej szybsze przekazanie do realizacji na hali produkcyjnej. Uruchomiona na tej podstawie produkcja może być monitorowana poprzez uproszczone raportowanie wykonania zadań technologicznych w oparciu o rzeczywiste działania na hali produkcyjnej. Tak zgromadzone dane stanowią jedno $\mathrm{z}$ najbardziej wartościowych źródeł wiedzy na temat funkcjonowania systemu produkcyjnego i całego przedsiębiorstwa. Opisane rozwiązanie, poprzez uproszczenie działań i zakresów danych, odpowiada również na jedno z ograniczeń związanych z użytkowaniem zintegrowanych systemów klasy ERP (Enterprise Resource Planning) polegające na wymogu posiadania kompletnych i szczegółowych danych o produkcie i jego procesie wytwarzania, aby można było w pełni korzystać $\mathrm{z}$ oferowanej przez te systemy funkcjonalności. Prezentowana koncepcja może być wykorzystana do zgromadzenia pełnej wiedzy o procesach przedsiębiorstwa przed wdrożeniem lub uruchomieniem zaawansowanych zintegrowanych systemów lub modułów do szczegółowego harmonogramowania oraz rozliczania produkcji.
\end{abstract}

Słowa kluczowe: struktura produktu, projektowanie, przygotowanie produkcji, harmonogramowanie produkcji, produkcja w toku.

\footnotetext{
${ }^{1}$ Dr inż. Mariusz Cholewa, Wydział Mechaniczny/Katedra Technologii Laserowych, Automatyzacji i Organizacji Produkcji, Politechnika Wrocławska, ul. Łukasiewicza 5, 50-371 Wrocław; tel. 713203137; e-mail: mariusz.cholewa@pwr.edu.pl.

Mariusz Cholewa, PhD, Eng, Wroclaw University of Science and Technology, Faculty of Mechanical Engineering, ul. Łukasiewicza 5, 50-371 Wrocław; mobile: 0048713203137; e-mail: mariusz.cholewa@pwr.edu.pl.

${ }^{2}$ Dr inż. Jacek Czajka, Wydział Mechaniczny/Katedra Technologii Laserowych, Automatyzacji i Organizacji Produkcji, Politechnika Wrocławska, ul. Łukasiewicza 5, 50-371 Wrocław; tel. 713203137; e-mail: jacek.czajka@pwr.edu.pl (autor korespondencyjny).

Jacek Czajka, PhD, Eng, Wroclaw University of Science and Technology, Faculty of Mechanical Engineering, ul. Łukasiewicza 5, 50-371 Wrocław; mobile: 0048713203137; e-mail: jacek. czajka@pwr.edu.pl (corresponding author).
} 


\section{WPROWADZENIE}

Przedsiębiorstwa produkcyjne chcąc kontrolować swoje procesy biznesowe, a przez to podnieść efektywność swojego funkcjonowania wdrażają rozwiązania informatyczne do zarządzania - wdrażają systemy ERP. Systemy te posiadają szeroki zakres funkcji integrujących różne obszary przedsiębiorstwa z jednoczesną kontrolą kosztów oraz terminów realizacji zamówień od klientów ${ }^{3}$. W zakresie realizacji produkcji najważniejszymi funkcjami dla kadry zarządzającej są te, które umożliwiają zaplanowanie produkcji, monitorowanie jej zaawansowania oraz rozliczenia kosztów. Duże nadzieje wiązane są z modułami do planowania i sterowania produkcją, a dokładniej - do budowania harmonogramów, które pozwolą szczegółowo zaplanować terminy realizacji zamówień z podziałem na zadania przy uwzględnieniu rzeczywistej dostępności stanowisk pracy. Wdrażając takie systemy przedsiębiorstwa oczekują, że dzięki wdrożeniu modułu do zarządzania produkcją będzie można monitorować produkcję $\mathrm{w}$ toku, a przez to poprawić terminowość realizacji zleceń i w oparciu o te dane podejmować decyzje odnośnie do przyjmowania nowych zamówień. Przedsiębiorstwa liczą na to, że po wdrożeniu systemu ERP będą mogły być bardziej elastyczne w stosunku do wymagań klienta w zakresie wymagan ilościowych i oczekiwań co do terminów realizacji zamówień mając pełny obraz tego co dzieje się na hali odnośnie procesu i wykorzystania zasobów produkcyjnych ${ }^{4}$.

Wdrożenie systemu ERP angażuje duże nakłady finansowe i czasowe, a nie zawsze wyniki powdrożeniowe są zgodne $\mathrm{z}$ oczekiwaniami kadry zarządzającej. Korzyści są zwykle widoczne w obszarze logistyki i gospodarki magazynowej oraz księgowości w postaci ograniczenia zapasów i pełnej kontroli operacji finansowych. Poprawne wdrożenie systemu ERP może również przynieść korzyści w postaci standaryzacji procesów biznesowych, możliwość ich automatyzacji i kontroli w czasie rzeczywistym ${ }^{5}$. W wielu systemach generowanie harmonogramów produkcyjnych jest procesem czasochłonnym, angażującym duże zasoby obliczeniowe infrastruktury informatycznej firmy. Dlatego często harmonogramy te generowane są co kilka dni, najczęściej raz w tygodniu, co uniemożliwia szybką reakcję na pojawiające się zakłócenia na poziomie hali produkcyjnej. W takiej sytuacji konieczne jest wdrożenie kolejnego modułu systemu - systemu realizacji produkcji MES (Manufacturing Execution System), który dostarczy w czasie rzeczywistym informacji na temat wykorzystania maszyn i zaawansowania produkcji $\mathrm{w}$ toku poprzez ewidencję zdarzeń zachodzących podczas produkcji ${ }^{6}$. Dane mogą być zbierane bezpośrednio z maszyn $\mathrm{z}$ ich układów sterowania oraz przy udziale pracowników, którzy raportują realizowane zadania. Należy dokonać porównania danych zawartych $\mathrm{w}$ harmonogramie produkcji $\mathrm{z}$ danymi rzeczywistymi i podjąć stosowne decyzje

3 J. Czajka, M. Cholewa, System ONS jako uzupetnienie systemów ERP, „Mechanik” 2014, R. 87, nr 11, s. 910-912.

${ }^{4}$ R. Szeloch, S. Kłos, Analiza efektywności wykorzystania informatycznych systemów do wspomagania zarządzania produkcja, „Zarządzanie Przedsiębiorstwem” 2015, Vol. 18, nr 2, s. 33-39; R. Wolniak, P. Hąbek, Computer aided sustainable development reporting - integration with ERP Packages [w:] Systems Supporting Production Engineering. Review of Problems and Solutions, red. J. Kaźmierczak, Gliwice 2014, s. 119-127.

5 A.C. Caraiman, Advantages and disadvantages of using integrated ERP systems at trade entities, “Annals of the „Constantin Brâncuşi” University of Târgu Jiu, Economy Series, Issue 4/2015.

${ }^{6}$ E. Arica, D.J. Powell, A framework for ICT-enabled real-time production planning and control, Advances in Manufacturing, June 2014, Vol. 2, pp. 158-164. 
w przypadku zagrożenia niedotrzymania terminów zadeklarowanych klientom. System MES dostarcza informacje o liczbie wyprodukowanych części, ale również o powstałych podczas produkcji brakach. To również może skutkować tym, że harmonogram produkcji będzie musiał być zmodyfikowany. Systemy MES wspomagają realizację produkcji, pozwalają na jej monitorowanie i kontrolują związane z nią działania na hali produkcyjnej ${ }^{7}$. Informacja o wykorzystaniu zasobów może być podstawą działań mających na celu eliminację marnotrawstwa czy wąskich gardeł co w efekcie końcowym skutkuje podniesieniem efektywności produkcji.

Innym ważnym rozwiązaniem informatycznym, które pozwala kontrolować procesy przedsiębiorstwa na wielu etapach rozwoju produktu i jego wytwarzania jest system do zarządzania cyklem życia produktu (PLM - Product Lifecycle Management). Rozwiązanie to umożliwia gromadzenie danych o produkcie oraz dostarcza oczekiwanej przez użytkowników funkcjonalności od pierwszych faz życia produktu, poprzez jego projektowanie konstrukcyjne i technologiczne, wytwarzanie, wsparcie produktu u klienta włącznie $\mathrm{z}$ wycofaniem produktu z życia. PLM jest więc z założenia idealnym integratorem wszelkich działań i danych generowanych podczas życia produktu. Efektywne wdrożenie systemu PLM jest bardzo trudne, przede wszystkim dlatego, że PLM jest raczej strategią i koncepcją działania przedsiębiorstwa, a nie zbiorem rozwiązań IT, które należy skutecznie ze sobą zintegrować. Zresztą sama integracja IT i utrzymanie spójności danych w tych rozproszonych systemach jest samo w sobie zadaniem trudnym i skomplikowanym. Stąd często porównuje się proces wdrażania systemów klasy PLM do procesu wdrażania zintegrowanego rozwiązania ERP zarówno w aspekcie czasowym jak i kosztowym. Stąd niewiele przedsiębiorstw decyduje się na pełne wdrożenie systemu PLM, zazwyczaj kończąc proces wdrażania na jednym z bazowych jego elementów - wdrożeniu systemu do zarządzenia danymi o produkcie (PDM - Product Data Management).

Kolejnym modułem, który wdrażają przedsiębiorstwa jest moduł do zarządzania utrzymaniem ruchu. Może to być oddzielna aplikacja klasy CMMS (Computerized Maintenance Management Systems) lub moduł systemu ERP. Moduł do utrzymania ruchu może pobierać z systemu MES informacje o nieplanowanych przestojach i informować odpowiedzialne służby o zaistniałej sytuacji. Informacje o tego typu zdarzeniach również są istotne dla osób planujących produkcję i mogą skutkować wprowadzeniem zmian w harmonogramie. Dodatkowo harmonogram produkcji powinien również uwzględniać zdarzenia zaplanowane przez dział utrzymania ruchu, które ujęto w kalendarzu danego stanowiska - np. planowany przegląd.

\section{IDENTYFIKACJA PROBLEMU}

Wdrożenie zintegrowanego systemu do zarządzania produkcją nie zawsze kończy się sukcesem. Przyczyny niepowodzenia mogą wynikać z tego, że firma nie jest przygotowana do tego, aby zasilać system odpowiednimi danymi. Chodzi głównie o dane opracowywane w obszarze rozwoju produktu. Problemem może być to, że do wygenerowania harmonogramu produkcji wymagane są szczegółowe dane technologiczne w postaci procesów rozpisanych na operacje. Każda operacja powinna mieć przypisane stanowisko pracy oraz normatywy materiałowe i czasowe. Przy złożonych produktach występujących np.

\footnotetext{
7 A. Lenart, System realizacji produkcji jako rozszerzenie systemu ERP [w:] Komputerowo zinte-
} growane zarzadzanie, red. R. Knosala, t. 2, Opole 2009, s. 107-114. 
w branży maszynowej opracowanie tak szczegółowych zapisów dla procesu technologicznego wymaga dużych nakładów pracy z uwagi na to, że każdy produkowany element musi mieć przypisany proces technologiczny. Skompletowanie dokumentacji dla całego produktu umożliwia uruchomienie modułu do planowania produkcji i wygenerowanie harmonogramów. Przy złożonych produktach trudno jest spełnić ten wymóg. Dodatkowym utrudnieniem jest to, że systemy ERP zwykle nie posiadają zawansowanych modułów wspomagających projektowanie technologiczne w powiązaniu z danymi konstrukcyjnymi zamieszczonymi w strukturze produktu. Duża czasochłonność opracowania procesów technologicznych oraz brak wsparcia ze strony systemów ERP w zakresie planowania technologicznego powoduje, że wiele firm nie jest w stanie przygotować tych danych, a w efekcie końcowym uruchomić modułu do planowania produkcji. Nawet jeżeli uda się uruchomić harmonogramowanie produkcji to potrzebni są dodatkowi pracownicy, którzy będą zajmowali się planowaniem produkcji oraz na bieżąco modyfikowali plan na podstawie informacji zwrotnej z hali. Głównie chodzi o różnego rodzaju zakłócenia zaburzające plan produkcji - niedostępny zasób, niedostarczony materiał na czas i inne. Bardzo często dzieje się tak, że plan produkcji już w momencie jego przekazania na produkcję jest nieaktualny z uwagi na występujące na hali zakłócenia.

Kolejnym problemem jest czas generowania harmonogramów produkcyjnych dla całego przedsiębiorstwa. Harmonogramy generowane raz lub dwa razy w tygodniu, uniemożliwiają skuteczną reakcję na pojawiające się na poziomie hali produkcyjnej zakłócenia. Na podstawie powyższych rozważań można stwierdzić, że efektywne planowanie produkcji z wykorzystaniem modułów do jej harmonogramowania jest możliwe jedynie $\mathrm{z}$ uwzględnieniem informacji zwrotnej z hali produkcyjnej. To wymaga nakładów finansowych na wdrożenie kolejnych modułów systemu informatycznego. Całe środowisko informatyczne powinno być zintegrowane, aby dane były dostępne online i umożliwiły reagowanie na bieżące zdarzenia. Wdrożenie tak szerokiego zakresu aplikacji to wysokie koszty oraz długi czas wdrożenia często sięgający nawet kilku lat.

Należy zadać sobie pytanie: czy jesteśmy w stanie sprawnie przygotować produkcję, a w szczególności budować precyzyjne harmonogramy i na ich podstawie uruchomić i kontrolować produkcję w toku oraz nią zarządzać?

Powyższe obserwacje pozwalają na postawienie tezy, że jednym z istotnych czynników skutecznie blokujących powszechne korzystanie z harmonogramowania produkcji, a następnie jej raportowania jest trudność w zapewnieniu danych opisujących proces technologiczny wykonania wyrobu oraz dostarczeniu informacji o aktualnej sytuacji na hali produkcyjnej. Dlatego wydaje się, że pierwszym i logicznym krokiem rozpoczynającym proces uruchomienia zintegrowanego zarzadzania firmą w obszarze produkcji powinno być wdrożenie efektywnie działającego podsystemu IT niezbędnego przede wszystkim do zapewnienia wejściowych danych technologicznych oraz gromadzenia danych z poziomu hali produkcyjnej o zaawansowaniu produkcji i dostępności zasobów produkcyjnych. Podsystem ten umożliwi gromadzenie, a następnie zapewni dostęp do pełnych danych niezbędnych do generowania precyzyjnych harmonogramów i w konsekwencji zapewni wysoki stopień ich sprawdzalności. Poza tym proponowana koncepcja umożliwi wprowadzenie nowych zasad i kultury pracy na poziomie hali produkcyjnej.

Niniejsze opracowanie jest propozycją takiego podsystemu, w którym zaimplementowano koncepcję środowiska do przygotowania produkcji z założeniem, że stanowiska mają stuprocentową dostępność, a zapis procesu technologicznego wytwarzania jest uproszczony. Takie założenie pozwala na budowanie harmonogramów, które pozwalają 
na uruchomienie procesu zbierania danych o zaawansowaniu produkcji z hali produkcyjnej i na tej podstawie śledzenia zawansowania realizacji zleceń oraz gromadzenia danych o dostępności zasobów oraz rzeczywistych czasach trwania poszczególnych operacji technologicznych.

\section{MODEL SYSTEMU I STRUKTURA DANYCH}

Współpraca z klientem zwykle rozpoczyna się od pozyskania wymagań od klienta odnośnie produktu, a następnie złożenia oferty określającej warunki kosztowe i terminowe realizacji ${ }^{8}$. W przypadku akceptacji oferty dział handlowy rejestruje zamówienia w systemie ERP i rozpoczyna się proces jego realizacji. W przypadku produkcji jednostkowej czy też takiej, która musi spełnić specyficzne wymagania klienta pracę rozpoczyna dział projektowania produktu od przygotowania dokumentacji CAD dla części i złożeń, rysunków wykonawczych i innych danych oraz zestawień. Prace realizują konstruktorzy, a dodatkowo $\mathrm{w}$ proces projektowania produktu mogą być zaangażowani specjaliści z zakresu automatyki, elektroniki informatyki i inni. Środowiskiem współpracy dla tych działów może być system PDM stanowiący między innymi repozytorium dokumentów CAD i innych dokumentów. Systemy PDM umożliwiają efektywne zarządzanie strukturą produktu oraz dokumentacją techniczną . W przypadku złożonych produktów podstawą do dalszych prac nad produktem jest jego struktura, czyli hierarchiczny wykaz zespołów, podzespołów i części. Trzeba jednak mieć na uwadze, że obszar projektowania to nie tylko konstrukcja, ale również projektowanie technologiczne, które powinno być realizowane współbieżnie, a nie sekwencyjnie z uwagi na oszczędności czasowe. Moduły harmonogramujące produkcję wymagają, aby każdy wytwarzany element miał przypisaną marszrutę technologiczną wraz z danymi odnośnie stanowiska pracy oraz danymi czasowymi. Dla produktów o złożonej budowie przygotowanie tych danych jest czasochłonne i wymaga zatrudnienia pracowników o odpowiednich kwalifikacjach. Chcąc skrócić czas opracowania dokumentacji przedsiębiorstwa, szczególnie małe i średnie przedsiębiorstwa (MŚP), rezygnują z opracowania szczegółowej dokumentacji technologicznej, a produkcja często odbywa się na podstawie dokumentacji konstrukcyjnej, która jest przekazywana na hale produkcyjne. Przy takim podejściu cała odpowiedzialność za terminy i jakość produkcji spada na pracowników produkcyjnych. Nie ma możliwości budowania harmonogramów produkcyjnych oraz monitorowania produkcji $\mathrm{w}$ toku $\mathrm{z}$ uwagi na brak zapisu procesu technologicznego wytwarzania. W takiej sytuacji kłopotliwe staje się śledzenie obciążenia stanowisk pracy oraz zbieranie informacji o czasach pracy pracowników w powiązaniu z produktem i zleceniem. Komplikuje się zagadnienie planowania potrzeb materiałowych, zarządzania zakupami i zapasami. Ogólnie cały proces produkcyjny jest trudny do monitorowania, a co za tym idzie - kłopotliwe staje się deklarowanie terminów realizacji zamówień klientom. Marszruty technologiczne są więc kluczowe dla kolejnych etapów realizacji zleceń.

\footnotetext{
${ }^{8}$ M. Cholewa, Koncepcja zarządzania konstrukcyjna..., s. 1-10.

9 Tamże, s. 1-10; J. Czajka, M. Cholewa, Koncepcja środowiska do zarzadzania struktura produktu dla przedsiębiorstw o strukturze wielooddziałowej [w:] Innowacje $w$ zarzadzaniu $i$ inżynierii produkcji, red. R. Knosala, t. 1, Opole 2016, s. 269-276; J. Stark, Product Lifecycle Management: 21st Century Paradigm for Product Realisation - second edition, Springer - Verlag London Limited 2011.
} 
W dalszej części opracowania przedstawiono tok postępowania, który może sprawdzić się w przedsiębiorstwach o produkcji jednostkowej i małoseryjnej, w którym produkty nie podlegają transportowi międzyoperacyjnemu, np. z uwagi na ich gabaryty. Koncepcja ta jest pewnego rodzaju kompromisem dla opisanych wyżej wymagań i działań. Niezbędne jest do tego środowisko informatyczne działające według określonych zasad. Takie środowisko można zbudować $\mathrm{z}$ następujących, odpowiednio skonfigurowanych funkcjonalne, komponentów:

- System CAD będący źródłem danych konstrukcyjnych takich jak: modele, konstrukcyjna struktura produktu i inne dokumenty związane z produktem.

- System zarządzający dokumentacją konstrukcyjną i techniczną, np. system PDM.

- System ERP - moduł APS (Advanced Planning and Scheduling) systemu ERP lub aplikacja zewnętrzna, pracujący na podstawie struktury produktu pozyskanej z systemu CAD lub PDM. Uzupełnienie struktury produktu o dane technologiczne.

- System CAPP (Computer Aided Process Planning) jako moduł opcjonalny.

- Interfejs wymiany danych między CAD/PDM a ERP.

Koncepcja środowiska zakłada, że podstawą dalszych prac będzie konstrukcyjna struktura produktu, którą można pozyskać z systemu CAD lub z systemu PDM. W kolejnym kroku struktury produktu będzie uzupełniony o dane opisujące proces technologiczny wytwarzania tego produktu. Projektowanie technologiczne może odbywać się w systemie ERP, ale w wielu przypadkach nie jest to wygodne i ma duże ograniczenia funkcjonalne. Ograniczenia wynikają z zakresu integracji z systemami CAD/PDM, np. zazwyczaj nie ma możliwości przechowywania szkiców do operacji oraz wariantowania procesów.

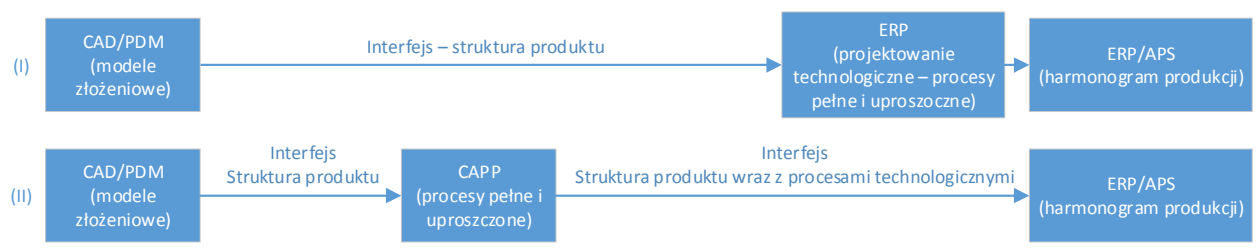

Rys. 1. Koncepcja środowiska informatycznego realizującego projektowanie technologiczne pełne i uproszczone

Źródło: opracowanie własne.

W takiej sytuacji przydatne może być wdrożenie zewnętrznej aplikacji do wspomagania projektowania procesów technologicznych - modułu CAPP. Jeżeli system ERP posiada dobrze rozwinięty moduł do planowania technologicznego to można zrezygnować z sytemu CAPP i konfigurację środowiska ograniczyć do zapewnienia możliwości wymiany danych między systemami CAD/PDM a ERP.

Na rys. 1 przedstawiono koncepcję działania takiego środowiska, w którym wyszczególniono dwie możliwe ścieżki przygotowania dokumentacji projektowej (I i II) w zależności od tego czy wdrożono system CAPP.

Moduł CAPP stanowi bazę wiedzy technologicznej, która usprawnia projektowanie procesu technologicznego poprzez udostępnienie biblioteki standardowych operacji i procesów, które można dołączać do struktury produktu i w razie potrzeby zmodyfikować 
- wariantować procesy ${ }^{10}$. Taki moduł umożliwia projektowanie kompletnych procesów technologicznych w powiązaniu z komponentami struktury produktu. Jak już wspomniano wcześniej projektowanie procesu technologicznego jest czasochłonne i ma znaczący wpływ na czas zakończenia opracowania dokumentacji produkcyjnej. Aby skrócić ten czas dla niektórych części lub zespołów można ograniczyć się do dołączenia meta procesu technologicznego składającego się z jednej meta operacji, np.: „Wykonać część” lub „Montaż domyślny”. Można również założyć, że system automatycznie będzie dołączał do każdej produkowanej części lub zespołu meta proces z jedną meta operacją, w sytuacji kiedy dany komponent już istnieje w bazie CAPP i nie ma wcześniej zdefiniowanego pełnego procesu. Działanie systemu CAPP może odbywać się według schematu zamieszczonego na rys. 2. Meta operacja musi również mieć zdefiniowany czas tpz (czas przygotowawczo-zakończeniowy) i tj (czas jednostkowy). Mogą to być domyślne dane (np. $\mathrm{tj}=1 \mathrm{~h}$, czas tpz może być zerowy), ale są one niezbędne do wygenerowania harmonogramu wstępnego.

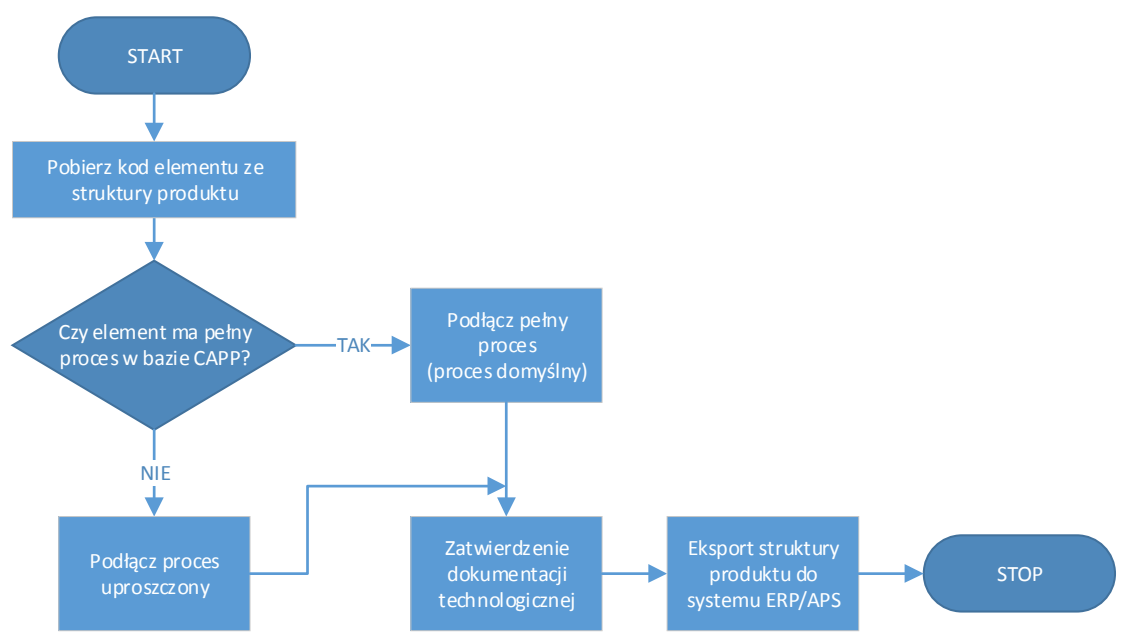

Rys. 2. Automatyczne dołączanie procesów technologicznych do struktury produktu - pełnych i uproszczonych

Źródło: opracowanie własne.

W razie potrzeby można proces domyślny - meta proces zastąpić kompletnym procesem podzielonym na operacje technologiczne. Źródłem takich danych mógłby być system CAPP typu wariantowego jako baza wiedzy technologicznej zorganizowana na zasadzie klasyfikatora, który zawiera gotowe zestawy danych, które można dołączyć do elementów struktury produktu. Dołączone do procesów stanowiska pracy można definiować na pewnym stopniu ogólności, jako np. brygada, wydział i inne. Tak zdefiniowany zestaw danych pozwala na wygenerowanie harmonogramu produkcyjnego. Taki harmonogram nie będzie miał pełnego odniesienia do rzeczywistości na hali produkcyjnej, ale pozwoli na wygenerowanie niezbędnej dokumentacji produkcyjnej (np. marszrut technologicznych/

${ }^{10}$ J. Czajka, M. Cholewa, Koncepcja środowiska do zarządzania strukturą..., s. 269-276. 
przewodników technologicznych, planów pracy dla stanowisk pracy), którą można przekazać do realizacji m.in. w celu zgromadzenia rzeczywistych danych z poziomu hali produkcyjnej.

Jak wcześniej wspomniano podstawowym elementem zapewniającym integrację i wymianę danych w ww. środowisku są dane opisujące strukturę produktu (ITEM, BOM). Dane, generowane w systemach CAD, pozyskiwane są poprzez wykorzystanie wbudowanych w systemach CAD mechanizmów eksportowych (tryb wsadowy) lub zaimplementowanego środowiska programistycznego API (Application Programming Interface). Pozyskane dane gromadzone są w systemie do zarządzenia dokumentacją konstrukcyjną i technologiczną. Systemy PDM mogą pełnić rolę ww. systemu. W takim przypadku dane o strukturze produktu można pozyskiwać bezpośrednio z bazy danych systemu PDM, który zazwyczaj jest zintegrowany z odpowiednim systemem CAD. Dane uproszczonych procesów technologicznych mogą być pozyskiwane z systemu CAPP lub też generowane przez odpowiednie procedury/makra w systemie do zarządzenia dokumentacją konstrukcyjną i technologiczną lub PDM. Bazodanowy zapis struktury produktu jest uzupełniany o dane opisujące proces technologiczny (ROUTING) ${ }^{11}$. Kompletny zestaw danych odejmujący: dane o produkcie (ITEM i BOM), proces technologiczny (ROUTING) oraz ich powiązanie (RELATION), stanowi wsad dla modułu do harmonogramowania produkcji, który może być składnikiem systemu ERP/APS. W prezentowanej koncepcji przewidziano również dodatkowy zestaw danych dla modułu do harmonogramowania produkcji zawierający dane zwrotne o aktualnej sytuacji na $\mathrm{z}$ hali produkcyjnej zawierający dane o zaawansowaniu produkcji (PRODUCTION_PRODUCT), dostępności stanowisk produkcyjnych (RESOURCE) $\mathrm{i}$ inne.

\section{PRZYKŁADOWE URUCHOMIENIE PRODUKCJI}

Danymi wejściowymi dla procesu przygotowania a następnie uruchomienia produkcji jest dokumentacja konstrukcyjna, a w zasadzie konstrukcyjna struktura produktu lub jej fragment. Struktura taka może być automatycznie tworzona i wprowadzana do systemu $\mathrm{z}$ wykorzystaniem interfejsów do systemów CAD w oparciu o modele $3 \mathrm{D}$ wyrobu ${ }^{12}$. Innymi metodami wprowadzania informacji o konstrukcyjnej strukturze produktu może być jej tworzenie w oparciu o pliki migracyjne generowane przez systemy CAD lub manualne wprowadzanie danych. Struktura produktu lub jej fragment jest niezbędna do utworzenia zlecenia produkcyjnego oraz pobrania domyślnych procesów technologicznych, które automatycznie mogą łączyć się z odpowiednimi pozycjami struktury produktu zgodnie ze schematem przedstawionym na rys. 2 .

Zlecenia produkcyjne zawierające opis produktu lub jego fragmentu - strukturę oraz proces technologiczny wytwarzania są gotowe do harmonogramowania - rys. 3.

Wynikiem harmonogramowania jest plan realizacji zlecenia produkcyjnego z uwzględnieniem aktualnej sytuacji na hali produkcyjnej. Harmonogramowanie może być dodatkowo sterowane parametrami określającymi: priorytet zlecenia produkcyjnego, planowaną datę uruchomienia produkcji lub planową datą jej zakończenia. Przykładowy harmonogram wygenerowany przez moduł do harmonogramowania np. z systemu ERP w postaci wykresu Gantta pokazano na rys. 4.

${ }^{11}$ M. Cholewa M., Koncepcja zarzqdzania konstrukcyjnq..., s. 1-10.

${ }^{12}$ J. Czajka, M. Cholewa, Koncepcja środowiska do zarzadzania strukturą.., s. 269-276. 


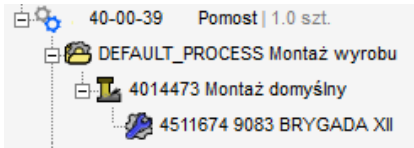

Rys. 3 Przykład konstrukcyjnej struktury produktu z procesem technologicznym zapisanym w sposób uproszczony

Źródło: opracowanie własne.

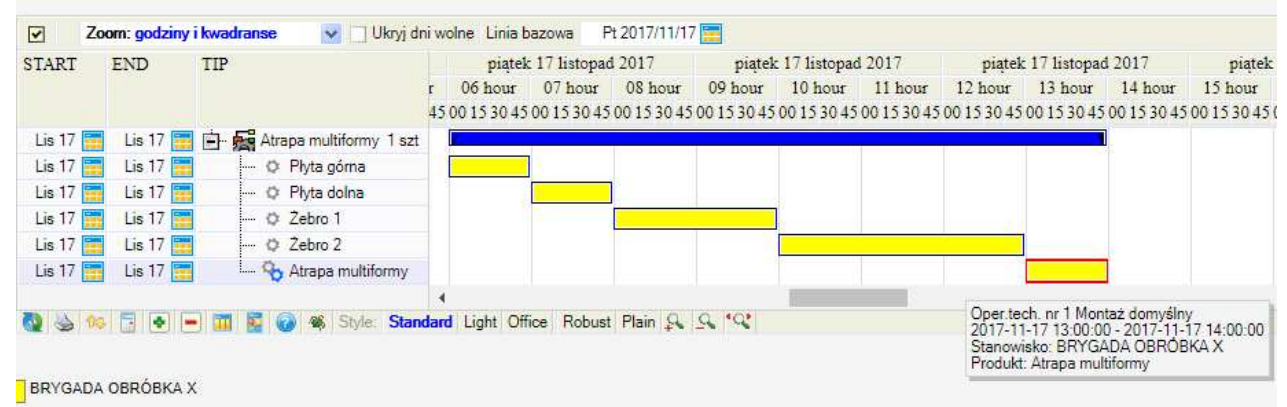

Rys. 4. Harmonogram zlecenia produkcyjnego

Źródło: opracowanie własne.

Tak opracowane dane mogą być emitowane/przekazane lub udostępnione pracownikom na hali produkcyjnej w postaci marszrut technologicznych lub specyfikacji operacji na poszczególnych stanowiskach pracy.

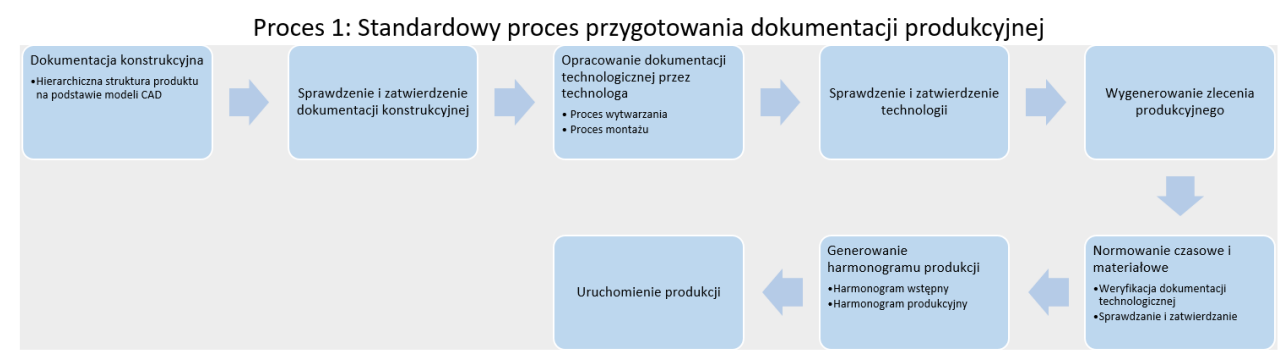

Proces 2: Uproszczony proces przygotowania dokumentacji produkcyjnej

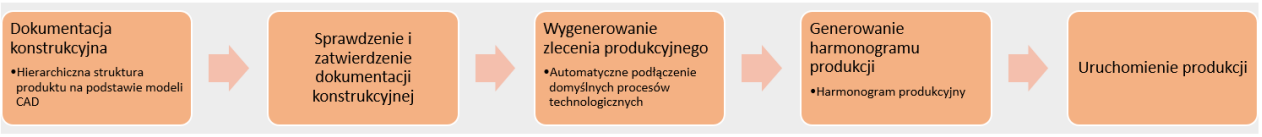

Rys. 5. Schemat postępowania podczas uruchamiania produkcji

Źródło: opracowanie własne. 
Opisana powyżej procedura postepowania została przedstawiona w sposób schematyczny na rys. 5. Łatwo zauważyć, że zaproponowany i opisany schemat postepowania jest znacznie uproszczony $\mathrm{w}$ stosunku do standardowego procesu przygotowania dokumentacji produkcyjnej. Uproszenie to pozwala znacznie zredukować czas związany $\mathrm{z}$ uruchomieniem produkcji zachowując pełną funkcjonalność w zakresie monitorowania i raportowania produkcji w toku. Opisana powyżej koncepcja usprawniania procesów przygotowania i uruchamiania produkcji może sprawdzić się, gdy mamy produkcję jednostkową i małoseryjną.

\section{RAPORTOWANIE PRODUKCJI W TOKU}

Dane pozyskiwane w oparciu o rzeczywiste działania na hali produkcyjnej stanowią jedno z najbardziej wartościowych źródeł danych opisujących działający system produkcyjny. Aby dane te rzeczywiście były wartością dla przedsiębiorstwa nie mogą być fragmentaryczne i wybiórcze - muszą w sposób kompletny, ilościowo i jakościowo, opisywać przebieg procesów, a proces ich pozyskiwania nie powinien być uciążliwy dla pracowników oraz nie powinien zakłócać przebiegu procesu produkcyjnego.

Raportowanie produkcji w toku odbywa się w oparciu o wygenerowaną dokumentację produkcyjną. Zawartość tej dokumentacji może być różna w poszczególnych przedsiębiorstwach, jednak zawsze jej zadaniem jest dostarczenie informacji o procesie technologicznym na poziom hali produkcyjnej oraz zachowanie powiązania pomiędzy raportowaną czynnością/zadaniem a zlecaniem produkcyjnym lub wytwarzanym produktem.

Raportowanie może być realizowane w różny sposób w zależności od dostępnej infrastruktury teleinformatycznej oraz wymagań stawianych przez osoby odpowiedzialne za zarządzanie produkcją odnośnie dokładności i aktualności zbieranych danych.

Wprowadzając system do raportowania zaawansowania produkcji należy umiejętnie znaleźć balans pomiędzy dokładnością monitorowania aktywności na poziomie hali produkcyjnej, a nakładem kosztów oraz pracy jaki wiąże się z utrzymaniem i obsługą takiego systemu, w tym należy uwzględnić czas pracowników poświęcany na czynności związane $\mathrm{z}$ raportowaniem produkcji.

Opisany w poprzednim rozdziale proces przygotowania i uruchomienia produkcji może współpracować, również z uproszczonym, procesem raportowania produkcji w toku. Zgodnie z wcześniej opisanym procesem przygotowania produkcji, każda część jest opisana jedną operacją technologiczną. Zarejestrowanie czasu rozpoczęcia jej realizacji oznacza początek procesu wytwarzania danej części, a jej zakończenia - koniec tego procesu. Pracownicy nie raportują szczegółowo poszczególnych operacji i czynności w procesie wytwarzania. Pomimo takiego uproszczenia system jest w stanie zgromadzić dane o:

- rzeczywistym czasie wytworzenia wszystkich części oraz montażu produktu i jego podzespołów,

- pracownikach zaangażowanych w wytwarzanie poszczególnych komponentów, jednocześnie przygotowując dane dla systemów kadrowo-płacowych o czasach pracy pracowników w poszczególnych zleceniach produkcyjnych w poszczególnych dniach miesiąca,

- zaangażowaniu poszczególnych zasobów produkcyjnych pozwalając na precyzyjną ocenę stopnia wykorzystania poszczególnych maszyn i stanowisk pracy w zadanych przedziałach czasowych. 


\section{WNIOSKI}

Mimo dynamicznego rozwoju systemów PDM/ERP w dalszym ciągu na rynku brakuje rozwiązań wspomagających prace działów odpowiedzialnych za przygotowanie dokumentacji technologicznej. Przedsiębiorstwa widząc potrzebę zorganizowania i uporządkowania pracy tego działu decydują się na wdrożenie dodatkowych rozwiązań i ich integrację z systemami nadrzędnymi - systemami ERP. Edytory procesów technologicznych dostępne w systemach ERP często niestety nie spełniają oczekiwań przedsiębiorstw ze względu na brak istotnych funkcji mających wpływ na efektywność prac. Przedstawione w opracowaniu podejście upraszcza ten etap i jednocześnie skraca czas opracowania dokumentacji produkcyjnej. Opisane rozwiązanie, poprzez uproszczenie działań i zakresów danych, odpowiada również na jedno $\mathrm{z}$ ograniczeń związanych $\mathrm{z}$ użytkowaniem zintegrowanych systemów klasy ERP polegające na wymogu posiadania kompletnych i szczegółowych danych o produkcie i jego procesie wytwarzania, aby można było w pełni korzystać z oferowanej przez te systemy funkcjonalności. Prezentowana koncepcja może być wykorzystana do zgromadzenia pełnej wiedzy o procesach przedsiębiorstwa przed wdrożeniem lub uruchomieniem zaawansowanych zintegrowanych systemów lub modułów do szczegółowego harmonogramowania oraz rozliczania produkcji.

Dla wielu firm ograniczenia prezentowanej koncepcji nie mają istnego wpływu na całościową ocenę rozwiązania, która w wielu przypadkach pozwala osiągnąć wymierne korzyści dla stosujących ją przedsiębiorstw. Pośród tych korzyści można wymienić:

- skrócenie czasu opracowania dokumentacji technologicznej,

- możliwość automatyzacji dołączania procesów technologicznych pełnych i domyślnych,

- możliwość wskazania realizacji operacji procesu domyślnego na grupie stanowisk,

- możliwość generowania harmonogramów produkcyjnych z możliwością zbierania czasów realizacji zadań technologicznych,

- możliwość śledzenia zaawansowania produkcji na podstawie zarejestrowanych czasów pracy,

- możliwość generowania kart zarobkowych na podstawie zarejestrowanych czasów pracy,

- możliwość elastycznego planowania obciążenia stanowisk na hali produkcyjnej,

- możliwość zdobycia wiedzy odnośnie czasochłonności realizowanych procesów,

- wprowadzenie standaryzacji w obszarze rozwoju produktu,

- podniesienie jakości dokumentacji technologicznej poprzez zastosowanie systemu CAPP stanowiącego bazę wiedzy technologicznej i źródło gotowych zestawów danych.

Opisana powyżej koncepcja usprawniania procesów przygotowania i uruchamiania produkcji może sprawdzić się, gdy mamy produkcję jednostkową i małoseryjną. Taka sytuacja ma bardzo często miejsce w przemyśle maszynowym.

Przedsiębiorstwa, które decydują się na taki sposób przygotowania i prowadzenia produkcji mają świadomość tego, że co prawda harmonogramowanie nie jest precyzyjne, ale łatwe raportowanie prac pozwala na skuteczne monitorowanie tego co dzieje się na hali produkcyjnej. Należy również zauważyć, że taki sposób przygotowania i prowadzenia produkcji powoduje, iż pracownicy produkcyjni muszą posiadać wysokie kwalifikacje, bo na nich spoczywa duża odpowiedzialność za jakość i terminowość realizowanych zleceń. 


\section{Literatura}

1. Arica E., Powell D.J., A framework for ICT-enabled real-time production planning and control, June 2014, Vol. 2, Issue 2.

2. Caraiman A.C., Advantages and disadvantages of using integrated ERP systems at trade entities, Annals of the „Constantin Brâncuşi” University of Târgu Jiu, Economy Series, Issue $4 / 2015$.

3. Cholewa M., Koncepcja zarzadzania konstrukcyjna i technologiczna struktura produktu w rozwoju złożonych produktów, „Mechanik” 2014, R. 87, $\mathrm{nr} 2$.

4. Czajka J., Cholewa M., System ONS jako uzupetnienie systemów ERP, „Mechanik” 2014, R. 87, nr 11.

5. Czajka J., Cholewa M., Koncepcja środowiska do zarzqdzania struktura produktu dla przedsiębiorstw o strukturze wielooddziatowej [w:] Innowacje $w$ zarządzaniu i inżynierii produkcji, red. R. Knosala, t. 1, Oficyna Wydawnicza Polskiego Towarzystwa Zarządzania Produkcją, Opole 2016.

6. Lenart A., System realizacji produkcji jako rozszerzenie systemu ERP [w:] Komputerowo zintegrowane zarzadzanie, red. R. Knosala, t. 2, Oficyna Wydawnicza Polskiego Towarzystwa Zarządzania Produkcją, Opole, 2009.

7. Stark J., Product Lifecycle Management: 21 st Century Paradigm for Product Realisationsecond edition. Springer - Verlag London Limited, 2011.

8. Szeloch R., Kłos S., Analiza efektywności wykorzystania informatycznych systemów do wspomagania zarządzania produkcją, „Zarządzanie Przedsiębiorstwem” 2015, Vol. 18, nr 2.

9. Wolniak R., Hąbek P., Computer aided sustainable development reporting - integration with ERP Packages [w:] Systems Supporting Production Engineering. Review of Problems and Solutions, red. J. Kaźmierczak, Wydawnictwo P.A.NOVA, Gliwice 2014.

\section{A CONCEPT FOR THE IMPROVEMENT OF PRODUCTION PREPARATION AND LAUNCH PROCESSES}

The paper presents the concept of an integrated IT environment that deliver functions in the field of developing technical documentation of the product, generating a production schedule and monitoring production in progress. The process and the data model assumes some changes in comparison to the traditional approach in the creating and describing of product manufacturing process plans, consisting on the use of simplified manufacturing process plans that are automatically attached to the product structure by the proposed IT system. The application of such a concept of work in the new product development departments will allow to shorten the time of development of the product's manufacturing documentation and its quicker distribution and application on the shop floor. Production run according this concept can be monitored by simplified reporting of the performance of technological tasks based on real activities on the shop floor. The data collected in this way is one of the most valuable sources of knowledge about the performing of the production system as well as the entire enterprise. The described solution, by simplifying activities and data ranges, also addresses one of the limitations related to the use of integrated ERP (Enterprise Resource Planning) class systems consisting in the requirement to have complete and detailed data about the product and its production process so that you can fully use the functionalities offered by these systems. The presented concept can be used to pre-gather full knowledge 
of the company's processes before implementing or launching sophisticated integrated systems or modules for detailed scheduling and production control.

Keywords: product structure, design, production preparation, production scheduling, production in progress.

DOI: 10.7862/rz.2018.mmr.1

Tekst złożono $w$ redakcji: styczeń $2018 r$.

Przyjęto do druku: kwiecień 2018 r. 
